\title{
FUNCTIONAL ANALYSIS OF GAIT WITH INSOLE USE IN DIABETIC FEMALE RATS: A CROSS-SECTIONAL STUDY
}

\author{
ANÁLISEFUNCIONAL DA MARCHA COM USO DE PALMILHAS EM RATAS DIABÉTICAS: \\ UMESTUDO TRANSVERSAL \\ ANÁLISIS FUNCIONAL DE LA MARCHA CON USO DE PLANTILLASEN RATAS DIABÉTICAS: \\ UNESTUDIO TRANSVERSAL
}

Original Article

ARTIGO ORIGINAL

Artículo Original

\begin{abstract}
Karla Camila Lima de Souza' ${ }^{1}$ (Physical Therapist)

Jonathan Elias Rodrigues Martins' ${ }^{1}$ (D) (Chemist)

Antônio Nadson Modesto Filho' (ID (Physical Therapist)

Jefferson Pacheco Amaral Fortes' ${ }^{1}$ (ID (Physical Therapist)

Denner Silvino da Silva' ${ }^{1}$ (ID

(Academician of the Biological

Sciences Course)

Francisco Fleury Uchoa (ID

Santos-Júnior ${ }^{1,2}$

(Physical Therapist)

Vânia Marilande Ceccatto' (iD

(Biologist)

\section{Universidade Estadual do Ceará - Biochemistry and Gene Expression Laboratory, Fortaleza, CE, Brazil. \\ 2. Centro Universitário Estácio do Ceará, Fortaleza, CE, Brazil.}

\section{Correspondence:}

Francisco Fleury Uchoa Santos Júnior

Rua Eliseu Uchôa Beco, 600, Água Fria, Fortaleza, CE, Brazil. 60810-270. francisco.uchoa@estacio.br.

\begin{abstract}
Introduction: Diabetes mellitus is a chronic disease that is characterized by causing damage to the peripheral nervous system, generating sensory and motor changes. Objective: This study aims at analyzing the impact of the use of different orthotic insoles on the gait of diabetic female rats. Methods: Twenty-six female Wistar rats were randomly divided into the Control and Diabetic groups. The mechanical sensitivity test was performed manually on the surface of the animals' hind paws using the von Frey test. The functional evaluation was carried out on an adapted platform where the animals were stimulated to walk in order to capture images of the ventral region for measurements of the right and left hind paws. After the images were collected they were processed using Kinovea software version 0.8.27 to assess: stride distance, time, speed and acceleration. Results: There was a reduction in the weight of the animals in the Diabetic Group ( $p=0.0018)$, associated with hyperglycemia ( $p=<0.0001$ ), and a decrease in mechanical sensitivity as compared to the Control Group $(p=0.0372)$. Gait analysis showed a reduction in stride speed $(p=0.0482)$ and acceleration $(p=0.0149)$, with the silicone orthosis in the Diabetic Group. Conclusions: The silicone orthosis demonstrated a reduction in stride speed and acceleration, without compromising the other variables in the diabetic rats. The other insoles showed no functional difference between groups. Even though the animals showed a change in sensitivity at the end of 28 days of DM induction, this time does not appear to have been able to develop extensive changes in the rats' gait function. Level of evidence Il; Therapeutic studies - Investigating the Results of Treatment.
\end{abstract}

Keywords: Diabetes mellitus; Gait; Orthosis.

\section{RESUMO}

Introdução: O diabetes mellitus é uma doença crônica que se caracteriza por causar danos no sistema nervoso periférico, gerando alterações sensitivas e motoras. Objetivos: O presente trabalho tem como objetivo analisar o impacto do uso de diferentes órteses do tipo palmilha sobre a marcha de ratas diabéticas. Métodos: Vinte e seis ratas Wistar foram divididas randomicamente nos grupos Controle e Diabético. O teste de sensibilidade mecânica foi realizado manualmente na superfície da pata traseira dos animais com o teste de von Frey. A avaliação funcional foi feita em plataforma adaptada, na qual as ratas foram estimuladas a deambular, a fim de captar imagens da região ventral para medições das patas traseiras direita e esquerda. Depois da coleta, as imagens foram processadas no software Kinovea versão 0.8.27 para avaliar distância, tempo, velocidade e aceleração de um passo. Resultados: Observou-se redução do peso dos animais no Grupo Diabético $(p=0,0018)$, associado à hiperglicemia $(p=<0,0001)$ e diminuição da sensibilidade mecânica em comparação como Grupo Controle $(p=0,0372)$. Na análise da marcha, verificou-se redução da velocidade $(p=0,0482)$ e aceleração de um passo $(p=0,0149)$ com a órtese de silicone no Grupo Diabético. Conclusões: A órtese de silicone demonstrou redução da velocidade e da aceleração do passo, sem comprometimento das demais variáveis nas ratas diabéticas. As demais palmilhas não demonstraram diferença funcional entre os grupos. Ainda que os animais tenham apresentado alteração de sensibilidade, ao final de 28 dias de indução do DM, esse tempo parece não ter sido capaz de desenvolver alterações amplas na função da marcha das ratas. Nível de evidência Il; Estudos terapêuticos - Investigação dos resultados do tratamento.

Descritores: Diabetes; Marcha; Órtese.

\section{RESUMEN}

Introducción: La diabetes mellitus es una enfermedad crónica que se caracteriza por causar daños al sistema nervioso periférico, generando alteraciones sensitivas y motoras. Objetivos: El presente trabajo tiene como objetivo analizar el impacto del uso de diferentes ortesis, del tipo plantilla sobre la marcha de ratas diabéticas. Métodos: Veintiséis ratas Wistar fueron divididas aleatoriamente en los grupos Control y Diabético. El test de sensibilidad mecánica fue realizado manualmente en la superficie de la pata trasera de los animales con el test de von Frey. La evaluación funcional fue hecha en plataforma adaptada, en la que se estimuló a las ratas a deambular, a fin de capturar imágenes de la región ventral para mediciones de las patas traseras derecha e izquierda. Después de la colecta, las imágenes se procesaron en el software Kinovea versión 0.8.27, para evaluar distancia, tiempo, velocidad y aceleración de un 
paso. Resultados: Se observó una reducción del peso de los animales en el Grupo Diabético ( $p=0,0018)$, asociado a la hiperglucemia ( $p=<0,0001$ ), y disminución en la sensibilidad mecánica en comparación con el Grupo Control $(p=0,0372)$. En el análisis de la marcha, se verificó reducción de la velocidad $(p=0,0482)$ y una aceleración de un paso $(p=0,0149)$, con la ortesis de silicona en el Grupo Diabético. Conclusiones: La ortesis de silicona demostró reducción de la velocidad y de la aceleración del paso, sin compromiso de las demás variables en las ratas diabéticas. Las demás plantillas no demostraron diferencia funcional entre los grupos. Aunque los animales hayan presentado alteración de la sensibilidad, al final de 28 días de inducción de DM, ese tiempo parece no haber sido capaz de desarrollar alteraciones amplias en la función de la marcha de las ratas. Nivel de evidencia ll; Estudios terapéuticos - Investigación de los resultados del tratamiento.

Descriptores: Diabetes mellitus; Marcha; Ortesis.

\section{INTRODUCTION}

Diabetes Mellitus (DM) is a chronic disease characterized by persistent hyperglycemia, resulting from defects in insulin secretion or action, or in both mechanisms, thereby causing complications. ${ }^{1}$ It is estimated that the disease will affect around 700.2 million people worldwide in 2045.2 The most common complications of DM include diabetic neuropathy, described as a heterogeneous set of clinical or subclinical manifestations, which attack the peripheral nervous system (PNS), with special emphasis on distal symmetric polyneuropathy as its most common clinical form, generally manifesting asymptomatically. ${ }^{3}$

Diabetic polyneuropathies, when associated with motor impairment, express a cumulative effect of thick fiber alteration - loss of proprioception, tactile, thermal and pain sensitivity, and involve a greater risk of skin lesions, infections, fractures, and Charcot joint destruction, in addition to changes in the position perception feedback from the receptors in the legs and feet as well as muscle weakness. In clinical terms, there are reports of typical neuropathic deformities resulting in increased plantar pressure and ulcerations. ${ }^{4}$

It is hypothesized that one of the ways to avoid diabetic foot complications is related to simple behaviors, such as: care for the feet and the use of adapted shoes and/or inclusion of orthopedic orthoses. ${ }^{1}$ In this context, it is essential to choose suitable materials to produce the orthosis, in order to make its use a success, since each material has particularities that can cause foot changes.

Accordingly, these aspects justify the increase in research on orthoses, since their production is important for avoiding and/or mitigating complications arising from the disease. Thus, this study aims to analyze the impact of the use of different types of orthotic insole on the gait of diabetic female rats.

\section{MATERIALS AND METHODS \\ Experimental group}

Twenty-six female Wistar rats (Rattus norvegicus) with an average age of 10 weeks and body mass between $150 \pm 250 \mathrm{~g}$ from the animal laboratory of Universidade Estadual do Ceará were used in the study. During the experimental period, the animals were kept in a light/dark cycle (12/12 h) in an environment with controlled temperature between 22 and $25^{\circ} \mathrm{C}$, and received feed and water ad libitum. The animals were randomly divided into two groups: Control $(n=13)$ and Diabetic $(n=$ 13). The study was approved by the Institutional Review Board for the Use of Animals under protocol no. 6923877 dated 10/28/2016.

To induce diabetes the female rats fasted overnight for 12 hours prior to induction. Induction consisted of a single dose of intraperitoneal streptozotocin (STZ) 65 mg/kg, Sigma Chemical Co.) dissolved in citrate buffer $(0.1 \mathrm{M})(\mathrm{pH} 4.5)$. The control group rats received a dose of the same volume of citrate buffer. Seventy-two hours after STZ administration, diabetes induction was confirmed by measuring blood glucose using a portable glucometer (ACCUCHECK Active ${ }^{T M}$, Ireland). Animals with blood glucose equal to or greater than $200 \mathrm{mg} / \mathrm{dL}$ were considered diabetic and used in the study. ${ }^{5}$

\section{Measurement of body weight and blood glucose}

Scales (Redplast, Brașov, Romania) were used to measure body weight and a portable glucometer (ACCUCHECK Active ${ }^{\mathrm{TM}}$, Ireland) to perform a blood glucose analysis. The measurements took place before diabetes induction in the animals, 48 hours after induction, and 16 and 28 days after induction.

\section{Orthopedic orthoses}

The criteria used to choose the materials were based on information contained in the literature. ${ }^{6}$ The chosen materials included: silicone (Redelease", São Paulo - SP, Brazil); prevulcanized latex, Hevea brasiliensis (Epoxfiber", Rio de Janeiro - RJ, Brazil); evapod ${ }^{\circledR}$ (Podaly Palmilhas LTDA ME, Brusque - SC, Brazil); and podadur ${ }^{\circledast}$ (Podaly Palmilhas LTDA ME, Brusque - SC, Brazil).

To build the orthosis models for the animals, the hind paw of each animal was pressed on a number 3 ink pad (Radex, Tonabras, São Paulo, SP, Brazil) using red ink to obtain the footprint (Figure 1A). With this image it was possible to design the orthosis mold in the proper measurements for each animal. After the orthosis was made, these were fixed to the

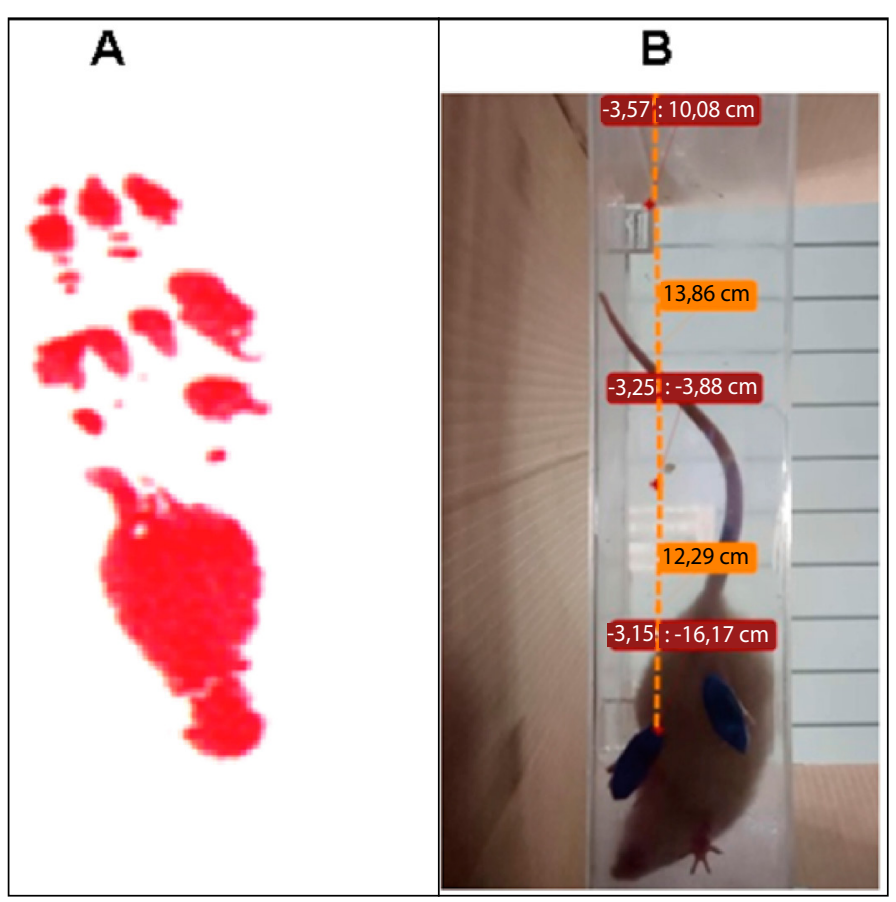

Figure 1. (A) Footprint of an animal paw. (B). Image of the animal filming platform. 
animals' hind paws (right and left) using $12 \mathrm{~mm}$ transparent adhesive tape (Aldebras, Vinhedo, SP, Brazil).

To assess mechanical sensitivity the animals were placed in acrylic cages with wire mesh floors and left to rest for five minutes. Mechanical sensitivity was then analyzed using a digital analgesiometer (Insight Equipamentos LTDA, Ribeirão Preto, SP, Brazil), with a von Frey rigid probe measuring $1.0 \mathrm{~mm}$ in diameter, applied manually to the plantar surface of the animals' hind paw until it produced a response characterized as rapid balancing/withdrawal of the stimulated paw. This procedure was repeated six times for each hind paw with an interval of approximately 30 seconds between measurements. ${ }^{7}$ These measurements took place prior to the induction of diabetes in the animals (TO), and 16 (T16) and 28 (T28) days after induction.

\section{Functional analysis}

The functional evaluation of the animals was carried out using a transparent acrylic platform (length $50 \mathrm{~cm} \times$ width $5 \mathrm{~cm} \times$ height $8 \mathrm{~cm}$ ), coupled at the end to a dark compartment (Figure 1B). The animals were stimulated to walk around inside the box in the direction of the dark environment. The images of the animals' gait were obtained by positioning an LG K12 Plus ${ }^{\text {TM }}$ cell phone (LG Electronics do Brasil LTDA) 16 MP camera at the bottom of the platform at a distance of $40 \mathrm{~cm}$. Filming was performed to collect images of the ventral region of the animals walking, in order to take measurements of the hind paws (right and left) of each animal. All animals underwent adaptation and were allowed to explore their environment. Filming took place 28 days after diabetes induction.

After the images were collected, they were stored and subsequently processed in Kinovea ${ }^{\mathrm{TM}}$ free software (version 0.8.27) under the GPL V2 license, where several frames were isolated. These frames contained the appropriate timing for analysis of the following parameters: stride distance $(\mathrm{cm})$; stride time $(\mathrm{s})$; speed $(\mathrm{cm} / \mathrm{s})$ and stride acceleration $(\mathrm{cm} / \mathrm{s})$.

For the statistical analysis we used the mean \pm standard deviation of the mean and compared the different groups. Two-way ANOVA (analysis of variance) with Sidak's post hoc test were used to analyze the tests, considering a statistical significance level of $p<0.05$. The analyses were carried out using GraphPad Prism 8.00 software (GraphPad Software, La Jolla, CA, USA).

\section{RESULTS}

In the characterization of the model, a reduction in the weight of the animals was observed in the diabetic group, associated with hyperglycemia and decreased mechanical sensitivity as compared to the control group (Table 1). Figure 2 shows the analysis of the animals' mechanical sensitivity at three different time points: $\mathrm{TO}$ (control 28.98 \pm 4.97; diabetic $30.05 \pm 4.58 ; p=0.8066$ ), T16 (control 39.34 \pm 6.27 ; diabetic $30.79 \pm 7.33 ; p=0.0005$ ) and T28 (control 60.11 \pm 11.46 ; diabetic $48.44 \pm$ $13.74 ; p=0.0372)$.

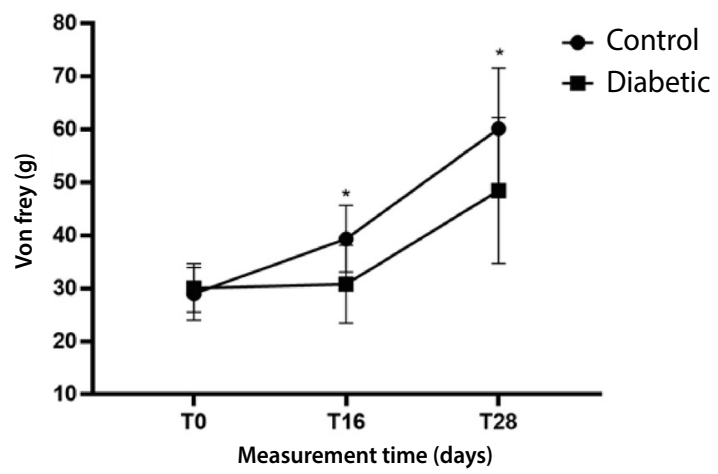

* $p<0.05$ versus control; Mean \pm standard deviation of the mean (SD); Two-way ANOVA with Sidak's post hoc test

Figure 2. Analysis of the mechanical sensitivity of the animals.

Table 2 contains the data on gait functionality in the control and diabetic animals when using different types of orthosis. In general, the two groups showed no difference in the use of different types of orthosis in terms of stride time and stride distance. However, in terms of stride speed and acceleration, the silicone insole used in the diabetic group revealed a reduction in speed $(p=0.0482)$ and stride acceleration $(p=0.0149)$.

\section{DISCUSSION}

The female rats in the control group experienced a progressive increase in body weight compared to the diabetic group, which showed a decrease in weight, thus confirming their catabolic state. This situation may be due to hypoinsulinism, which leads to a catabolic state of proteins and fats, as described by Moura et al. ${ }^{8}$ We noticed that the rats treated with STZ presented with hyperglycemia throughout the study in comparison to the control group, which is consistent with findings reported by Carvalho et al. ${ }^{9}$ Studies report that hyperglycemia due to DM can damage the cells responsible for PNS myelination, known as Schwann cells. ${ }^{10}$

The PNS is known to contain a large proportion of Schwann cells. These cells have the ability to capture glucose, playing a vital role in diabetic neuropathy as metabolic disorders are more pronounced in this cell. ${ }^{5}$ Considering that the myelin sheath is responsible for increasing conduction velocity, this pathology is expected to lead to changes in nerve and sensory conductivity. ${ }^{11}$

Alves et al. ${ }^{12}$ demonstrated that immobilization can cause fragmentation of the myelin sheath of the sciatic nerve with axon degeneration. Santos Júnior et al., ${ }^{13}$ in turn, reported that muscle disuse for two weeks promotes a selective sensorial adaptation (in this case, an increase in the thermal response and a decrease in the mechanical response), revealing that other conditions can directly infer neural function.

In this context, when analyzing the mechanical sensitivity of the animals, we found a reduction in the mechanical sensory perception of the diabetic female rats compared to the control group. This reduction can be justified

Table 1. Analysis of the increase/decrease in body weight and blood glucose levels of the animals.

\begin{tabular}{|c|c|c|c|c|c|c|c|c|}
\hline \multirow[b]{2}{*}{ Parameters } & \multirow[b]{2}{*}{ Period } & \multicolumn{2}{|l|}{ Control } & \multicolumn{2}{|l|}{ Diabetic } & \multicolumn{3}{|c|}{ Control-diabetic } \\
\hline & & Mean \pm SD & $\mathbf{n}$ & Mean \pm SD & $\mathbf{n}$ & $\begin{array}{c}\text { Mean } \\
\text { difference }\end{array}$ & $\begin{array}{c}95 \% \text { of the } \\
\text { Confidence interval }\end{array}$ & $p$-value \\
\hline \multirow{4}{*}{$\begin{array}{l}\text { Weight of the } \\
\text { animal (g) }\end{array}$} & Before the induction & $177.15 \pm 20.90$ & 13 & $168.15 \pm 18.28$ & 13 & 9.000 & -11.76 to 29.76 & 0.6908 \\
\hline & 48 hours after induction & $180.46 \pm 19.01$ & 13 & $144.53 \pm 12.46^{*}$ & 13 & 35.92 & 18.73 to 53.12 & $<0.0001$ \\
\hline & 16 days after induction & $190.92 \pm 20.50$ & 13 & $136.70 \pm 18.30^{*}$ & 10 & 54.22 & 32.07 to 76.37 & $<0.0001$ \\
\hline & 28 days after induction & $199.76 \pm 18.98$ & 13 & $143.28 \pm 25.34^{*}$ & 07 & 56.48 & 23.20 to 89.77 & 0.0018 \\
\hline \multirow{4}{*}{$\begin{array}{l}\text { Blood Glucose } \\
\qquad(\mathrm{mg} / \mathrm{dL})\end{array}$} & Before the induction & $64.23 \pm 15.10$ & 13 & $76.46 \pm 9.55$ & 13 & -12.23 & -25.77 to 1.313 & 0.0875 \\
\hline & 48 hours after induction & $104.76 \pm 8.36$ & 13 & $510.07 \pm 88.80^{*}$ & 13 & -405.3 & -477.4 to -333.2 & $<0.0001$ \\
\hline & 16 days after induction & $105.92 \pm 8.42$ & 13 & $481.50 \pm 62.43^{*}$ & 10 & -375.6 & -436.8 to -314.4 & $<0.0001$ \\
\hline & 28 days after induction & $115.92 \pm 14.30$ & 13 & $540.28 \pm 54.39^{*}$ & 07 & -424.4 & -495.8 to -352.9 & $<0.0001$ \\
\hline
\end{tabular}


Table 2. Functional analysis of the gait of diabetic female rats with different orthopedic orthoses for the hind paw.

\begin{tabular}{|c|c|c|c|c|c|c|c|c|}
\hline Parameters & Orthoses & $\begin{array}{c}\text { Control } \\
\text { Mean } \pm \text { SD }\end{array}$ & $n$ & $\begin{array}{c}\text { Diabetic } \\
\text { Mean } \pm \text { SD }\end{array}$ & $\mathrm{n}$ & Mean Difference & $\begin{array}{c}95 \% \text { of the } \\
\text { Confidence Interval }\end{array}$ & p-value \\
\hline \multirow{5}{*}{$\begin{array}{l}\text { Stride distance } \\
\qquad(\mathrm{cm})\end{array}$} & No Orthosis & $10.63 \pm 1.24$ & 26 & $10.82 \pm 1.72$ & 13 & -0.19 & -1.97 to 1.58 & 0.9995 \\
\hline & Evapod & $10.55 \pm 2.09$ & 26 & $9.43 \pm 1.94$ & 14 & 1.11 & -0.62 to 2.84 & 0.4048 \\
\hline & Podadur & $9.36 \pm 1.85$ & 25 & $8.63 \pm 2.26$ & 14 & 0.72 & -1.02 to 2.47 & 0.8098 \\
\hline & Silicone & $8.53 \pm 2.12$ & 24 & $7.62 \pm 3.19$ & 14 & 0.91 & -844 to 2.68 & 0.6247 \\
\hline & Latex & $11.27 \pm 1.63$ & 26 & $10.68 \pm 2.36$ & 14 & 0.58 & -1.15 to 2.32 & 0.9096 \\
\hline \multirow{5}{*}{$\begin{array}{l}\text { Stride time } \\
(\mathrm{s})\end{array}$} & No Orthosis & $18.21 \pm 2.74$ & 26 & $19.71 \pm 2.68$ & 13 & -1.5 & -14.98 to 11.98 & 0.9994 \\
\hline & Evapod & $25.87 \pm 18.99$ & 26 & $23.85 \pm 7.84$ & 14 & 2.01 & -11.14 to 15.17 & 0.9972 \\
\hline & Podadur & $29.02 \pm 35.20$ & 25 & $20.14 \pm 3.76$ & 14 & 8.88 & -4.36 to 22.13 & 0.3531 \\
\hline & Silicone & $19.45 \pm 7.93$ & 24 & $18.18 \pm 5.89$ & 13 & 1.27 & -12.39 to 14.94 & 0.9997 \\
\hline & Latex & $16.62 \pm 4.39$ & 26 & $21.50 \pm 8.25$ & 14 & -4.87 & -18.03 to 8.28 & 0.8725 \\
\hline \multirow{5}{*}{$\begin{array}{l}\text { Stride speed } \\
\qquad(\mathrm{cm} / \mathrm{s})\end{array}$} & No Orthosis & $0.60 \pm 0.11$ & 26 & $0.57 \pm 0.13$ & 13 & 0.03 & -0.62 to 0.69 & $>0.9999$ \\
\hline & Evapod & $0.56 \pm 0.15$ & 26 & $0.46 \pm 0.15$ & 14 & 0.10 & -0.53 to 0.74 & 0.9962 \\
\hline & Podadur & $0.51 \pm 0.28$ & 25 & $0.45 \pm 0.10$ & 14 & 0.05 & -0.58 to 0.70 & 0.9998 \\
\hline & Silicone & $0.55 \pm 0.19$ & 24 & $1.20 \pm 2.75^{*}$ & 14 & -0.65 & -1.30 to -0.003 & 0.0482 \\
\hline & Latex & $0.77 \pm 0.12$ & 26 & $0.56 \pm 0.15$ & 14 & 0.21 & -0.42 to 0.85 & 0.9110 \\
\hline \multirow{5}{*}{$\begin{array}{l}\text { Stride acceleration } \\
\qquad(\mathrm{cm} / \mathrm{s})\end{array}$} & No Orthosis & $0.03 \pm 0.01$ & 26 & $0.03 \pm 0.01$ & 13 & 0.006 & -0.66 to 0.67 & $>0.9999$ \\
\hline & Evapod & $0.11 \pm 0.14$ & 26 & $0.06 \pm 0.12$ & 14 & 0.04 & -0.60 to 0.70 & $>0.9999$ \\
\hline & Podadur & $0.07 \pm 0.12$ & 25 & $0.04 \pm 0.08$ & 14 & 0.03 & -0.63 to 0.69 & $>0.9999$ \\
\hline & Silicone & $0.08 \pm 0.12$ & 24 & $0.86 \pm 2.85^{*}$ & 14 & -0.77 & -1.43 to -0.10 & 0.0149 \\
\hline & Latex & $0.23 \pm 0.15$ & 26 & $0.07 \pm 0.12$ & 14 & 0.16 & -0.49 to 0.81 & 0.9758 \\
\hline
\end{tabular}

by a decrease in nerve excitability, amplitude and conduction velocity induced by DM, already reported in the literature. $5,7,14$ Santos et al..$^{15}$ describe that at the end of the $4^{\text {th }}$ week of induction with STZ, diabetes can affect several types of neurons, compromising electrophysiological properties of the nerves. Therefore, it is likely that the reduction in the sensitivity of the animals in this study is due to electrophysiological changes in nerves.

It is reported in the literature that diabetics experience changes in their gait pattern and stride amplitude as well as in mechanical sensitivity, due to the reduction in the transmission of proprioceptive information - plantar neuroreceptors - essential for normal gait. ${ }^{16,17}$ When analyzing the gait of diabetic animals, we ascertained that the silicone insole generated a decrease in the stride speed and acceleration of the animals as compared to the control group. The reduction in the podal sensitivity of the diabetic animals associated with the characteristics of the physicochemical constitution of the orthosis may have contributed to this finding, requiring a certain degree of additional adaptability from the diabetic group to the material/mechanical sensitivity ratio of the paw.

However, we did not observe any change in the gait pattern of the animals without orthosis or those using other orthopedic orthoses. This information is relevant, since the sensory alteration observed in the animals in this study does not appear to have had a considerable biomechanical impact on the gait of the diabetic animals, except in relation to the silicone insole. Godoi et al. ${ }^{18}$ evaluated biochemical and functional parameters of the post-muscle injury inflammatory process in diabetic rats, and demonstrated that the animals in the uninjured diabetic group as compared to the healthy (control) group did not exhibit any functional changes in gait, corroborating the findings of this particular study.

\section{Limitations of the study and outlook for the future}

As a limitation of the research project we observed the mortality rate of animals in the diabetic group at the end of the experiments, as a result of induction with STZ. However, this study opens up the possibility of investigating the chronic use of each type of insole and characterizing possible adaptations of the animals with regards to their use. As our results observed only one-time use with an immediate evaluation, the data support and suggest the continuity of studies, considering longer times of insole use by the animals and new methodologies for investigating the effects of their use by diabetics, including other investigative proposals, especially for nociception and functionality.

\section{CONCLUSIONS}

The results show that the one-time use of orthopedic insoles had no impact on the mechanical function of gait of diabetic animals, except for the silicone orthosis, which demonstrated a reduction in stride speed and acceleration, without compromising the other variables in diabetics. Even though the animals showed a change in sensitivity at the end of 28 days of DM induction, this time does not appear to have been able to develop changes in the animals' gait.

\section{ACKNOWLEDGMENTS}

To the Coordenação de Aperfeiçoamento de Pessoal de Nível Superior (Coordination for the Improvement of Higher Education) (CAPES); Conselho Nacional de Desenvolvimento Científico e Tecnológico (National Council for Scientific and Technological Development) (CNPQ) and Fundação Cearense de Apoio ao Desenvolvimento Científico e Tecnológico (Ceará State Foundation for Support to Scientific and Technological Development) (FUNCAP).

All authors declare no potential conflict of interest related to this article

AUTHORS' CONTRIBUTIONS: Each author made significant individual contributions to this manuscript. KCLS: writing, experimental analyses and filming, review and preparation of the entire research project; JERM: experimental analyses (induction of diabetes and mechanical sensitivity test) and filming; ANMF: filming and filming analysis; JPAF experimental analyses (induction of diabetes and mechanical sensitivity test) and filming; DSS: experimental analyses (weight, blood sugar levels and filming); FFUSJ: intellectual concept, writing, statistical analysis, critical review and supervision of the project; VMC: critical review and supervision of the project. All authors read and approved the final version of the article. 


\section{REFERENCES}

1. Sociedade Brasileira de Diabetes. Diretrizes da Sociedade Brasileira de Diabetes 2019-2020. 2019 [access 2020 Jan 26];1-491. Available at: https://www.diabetes.org.br/profissionais/images/ DIRETRIZES-COMPLETA-2019-2020.pdf.

2. International Diabetes Federation. Diabetes Atlas De La FID. 2019 [access on 2020 Jan 26]:1-176 Available at: https://diabetesatlas.org/upload/resources/material/20200106_152211_IDFATLAS9efinal-web.pdf.

3. Nascimento OJ, Pupe CC, Cavalcanti EB. Neuropatia diabética. Rev Dor. 2016;17(Suppl 1):S46-51.

4. van Schie CH. Neuropathy: mobility and quality of life. Diabetes Metab Res. 2008;24(Suppl 1):S45-51.

5. Farias VX, Uchoa PN, Aquino CP, Britto LR, Fonteles MC, Leal-Cardoso JH, et al. Expression of myo-inositol cotransporters in the sciatic nerve and dorsal root ganglia in experimental diabetes. Braz J Med Biol Res. 2019;52(6):e8589.

6. Cunha JA, Carneiro MR, Souza KC, Santos Júnior FF, Ceccatto VM. Biomaterials characterization for orthopedic orthoses: a systematic review. J Mater Sci Nanotechnol. 2019;7(1):101.

7. Silva FW, Alves KS, Santos ML, Oliveira KA, Joca HC, Vale OC, et al. n5-STZ Diabetic model develops alterations in sciatic nerve and dorsal root gang lia neurons of wistar rats. ISRN Endocrinol. 2013;2013:638028.

8. Moura LP, Gomes RJ, Leme JA, Voltarelli FA, Ribeiro C, Moura RF, et al. Pancreatic insulin of type I diabetic rats subjected to an individualized exercise-training protocol. Motricidade. 2012;8(1):23-32.

9. Carvalho C, Ferreira BB, Grilo CS, Urias GM, Akisue G. The glycemic profile of diabetic female rats alloxan-induced treated with Momordica charantia L. Rev Ciên Saúde. 2016;1(1):37-44.

10. Freeman OJ, Unwin RD, Dowsey AW, Begley P, Ali S, Hollywood KA. et al. Metabolic dysfunction is restricted to the sciatic nerve in experimental diabetic neuropathy. Diabetes. 2016;65(1):228-38.

11. Lirk P, Verhamme C, Boeckh R, Stevens MF, Hoope WT, Gerner P. et al. Effects of early and late diabetic neuropathy on sciatic nerve block duration and neurotoxicity in Zucker diabetic fatty rats. Br J Anaesth. 2015;114(2):319-26.

12. Alves JS, Leal-Cardoso JH, Santos Júnior FF, Carlos PS, Silva RC, Lucci CM. et al. Limb immobilization alters functional electrophysiological parameters of sciatic nerve. Braz J Med Biol Res. 2013;46(8):715-21.

13. Santos Júnior FF, Pires AF, Ribeiro NM, Mendonça VA, Alves JO, Soares PM. et al. Sensorial, structura and functional response of rats subjected to hind limb immobilization. Life Sci. 2015;137:158-63.

14. Nascimento PS, Lovatel GA, Ilha J, Schaan BD, Achaval M. Diabetes increases mechanical sensitivity and causes morphological abnormalities in the sural nerve that are prevented by treadmill training Muscle Nerve. 2013:47(1):46-52

15. Santos NM, Abreu KO, Moreira-Júnior L, Nascimento TS, Alves KS, Souza NA, et al. Diabetes mellitus alters electrophysiological properties in neurons of superior cervical ganglion of rats. Brain Res. 2020;1729:146599.

16. Fregonesi CE, Camargo MR. Gait parameters in patients with diabetes mellitus. Rev Bras Cineantropom Desempenho Hum. 2010;12(2):155-63.

17. Saura V, Santos AL, Ortiz RT, Parisi MC, Fernandes TD, Nery M. Predictive factors of gait in neuropathic and non-neurophatic diabetic patients. Acta Ortop Bras. 2010;18(3):148-51.

18. Godoi V, Rossi RP, Pallota RC, Tomazoni SS, Teixeira S, Ramos L. Evaluation of muscle injury after controlled stretching in diabetic rats. ConScientiae Saúde. 2011;10(2):201-9.

In the article entitled "FUNCTIONAL ANALYSIS OF GAIT WITH INSOLE USE IN DIABETIC FEMALE RATS: A CROSS-SECTIONAL STUDY" authored by Souza Karla Camila Lima de, Martins Jonathan Elias Rodrigues, Modesto Filho Antônio Nadson, Fortes Jefferson Pacheco Amaral, Silva Denner Silvino da, Santos-Júnior Francisco Fleury Uchoa et al. published in Rev Bras Med Esporte. 26( 5 ): 386-390. DOI: http://dx.doi. org/10.1590/1517-8692202026052020_0017, by request of the authors:

Where it reads: Denner Silvino da Silva, Academician of the Biological Sciences Course, Physical Therapist ${ }^{1}$ Read: Denner Silvino da Silva, Academician of the Biological Sciences Course 